\title{
PELITA
}

\section{SYSTEMATIC ANALYSIS OF THE DOMINANT TYPES OF ENTOMOPHAGES IN FRUIT ORCHARDS}

M.K.Pakhmanova,K.Q.Kh amdamov, U.Rasulova, G.Turdiyeva,G.Rahmonov $a, \mathcal{E R}$. Saliyeva

\begin{abstract}
:
The formation of entomophauna in orchards and their development has a great importance, and it greatly influences to the number of phitofags. During our observations of entomophages orchard in agrobiocenosis indentified 24 dominant types which belong to seven families. Moveover, researches of entomophages show 24 dominant types which belong to 7 families. Besides that we have analysed the share of entomophage varieties concerning the entomophages.
\end{abstract}

\section{Tashkent Agrarian \\ University, Andijan \\ pakhmanova@gmail.com, \\ k.qkhamdamov@ramler.ru \\ , u.rasulova@mail.ru, \\ g.turdiyeva@umail.uz, g.rahmonova@gmail.com,}

r.saliyeva@gmail.com.

Keywords: orchard, pest entomophage, entomofauna, parasites, areal, type, family

\section{A. INTRODUCTION}

In recent years, due to the expansion of horticulture, especially intensive gardens, changes in the structure of agricultural crops in the country have led to changes in the structure of the food chain over the years, the emergence of new species of entomophages, and the protection of fruit from pests, it requires a scientific approach to increase the importance of countermeasure activities(Thomas, Thanopoulos, Knüpffer, \& Bebeli, 2013).

As we know, most of the horticultural products grown in agriculture are lost through pests. Leaf clusters and fruit eaters are the main ones. It is observed that $75-80 \%$ of the annual fruit was lost by only one apple fruit eater. The use of environmentally friendly methods is one of the requirements of today. For this purpose it is important to form entomofauna in agrobietsenosis and to use entomophagous species according to pest type.

Bio-laboratories and biological factories established in the country produce a large number of bio-products. Basically, the parasites of the pest and beneficial insects likeTrichogramma, ladybird and Braconidae, which are bred in biolaboratory conditions and released to the field in order to maintain the yield. 


\section{PELITA}

The use of entomophagous egg-eater trichogramm is important in the protection of agricultural crops(Egamberdieva, Kamilova, ..., \& 2008, n.d.).

\section{Literature review}

In horticulture, parasitic egg-eater entomophages are able to reduce pests by up to 70\% (Shternshis M.V. 2004). In Central Asia, it has been reported that in gardening, there are 34 species of ichneo-amide, which are found in 17 species of parasites from the entomophagous family of Braconidae (Kopaneva L.M. 1984).

It is necessary to protect high quality fruit from fruit trees and their protection against various harmful organisms. It is well known to experts that the following insecticides harm fruit orchards: plant louse (Aphididae), fruit mite (Tetranychus viennensis Zacher), leaf lice (Aphidodea), coccidia (Coccidia), apple bug (Stephanitis). Bronze beetles (Cetoniini), bud moth (Tmetocera ocellana F), leaf moth (Recarvaria nanella Schiff), sheath moth (Coleophora hemerobiola elephant), rust moth (Semiostoma scitella Zell), spring blue butterfly (Cyaniris argiol), silk worm of grape (Laspeyrisia molesta Busk) and others.

More than 10,000 species of entomophages have been identified in nature in 224 families of 14 categories, of which $70 \%$ are fed with the most dangerous pests in agrobiocenosis (Saulich A.X., Musolin D.L., 2013).

\section{B. RESEARCH MATERIALS AND METHODS}

Observations on fruit gardens have been made by the number and type of beneficial insects. It studied the predatory and parasitic entomophages found in their crops and their cells. Some of the most effective species in the laboratory have been developed and applied in the laboratory, and are now being introduced to gardening farms in Chrysopidae. Our observations were conducted on some gardening farm grounds in Izboskan district of Andijan region. In early spring emerging of entomophages and phytophages from the winter, the formation of entomofauna in the garden, variation in species density within the environment, and additional factors such as entomophage reserve formation were carried out. Entomophages and phytophages were used in the sample collection of entomological species and light-retaining handles. The collected specimens were analyzed systematically by detectors in laboratory conditions(Craumer, 1995; Kalpakjian \& Schmid, 2014). 


\section{PELITA}

\section{RESULTS OF THE STUDY}

According to the data collected, the number of parasitic entomophages is higher than that of wild entomophages.

The Tachinidae family accounted for 16.2\%, and Exorista tarvarum, Exasnthaspis, Gonia cilipeda, Spallanzania hebes, Tachina rohdendorfi were marked as the dominant species.

According to it, the braconidae family was $42.4 \%$, and the dominant species were Apanteles talengai A. Vanessae: A. Spectabilis, Bracon hebetor, Rogas dimidiatus, R. pallidator, R. rossicus.

Ichneumonidd - family members are more frequent than other parasitic entomophages and make up $18.6 \%$ of total entomophages. The main reason for this is the abundance of host species of this species, and the fact that one parasite feeds on multiple species and the favorable climate. The Aphelinidae family comprised 9.5\%, and the species of Praonabjecrum, P. dorsale, Aphidius screen, Aphelinusspecies were recorded as dominant.

The Coccinellidae family is $14.7 \%$ with Coccinella septempunctata L, Adonia variegata Gz., Coccinula elegantura Ws. registered as a dominant species. The Shrysopidae family comprises 18.2\%, with the dominant species being Chrylsopa cornea Steph., Chrysopa septempunctata Wesm. Chrusopa albolineata Kill. The Trichogrammatfdae family is reported as $8.4 \%$ of the total parasites and there are species like Trichogrammatfda evanescens. Trichogramma embryophagum.During the laboratory analysis of collected species in the laboratory, the host species of entomophages were also studied. During the study some new species were registered and their biological characteristics were studied. At the same time, the Elasmus albipennis species of the Chalcidoidae family was first identified in mature local caterpillars of apple fruit. Researches were carried out to study the biological characteristics of this species in the Andijan region. The literature reveals that parasites occur mainly in European countries, as well as from the CIS countries - Azerbaijan, Turkmenistan, Georgia, and Russia(Dennis et al., 2007). 


\section{PELITA}

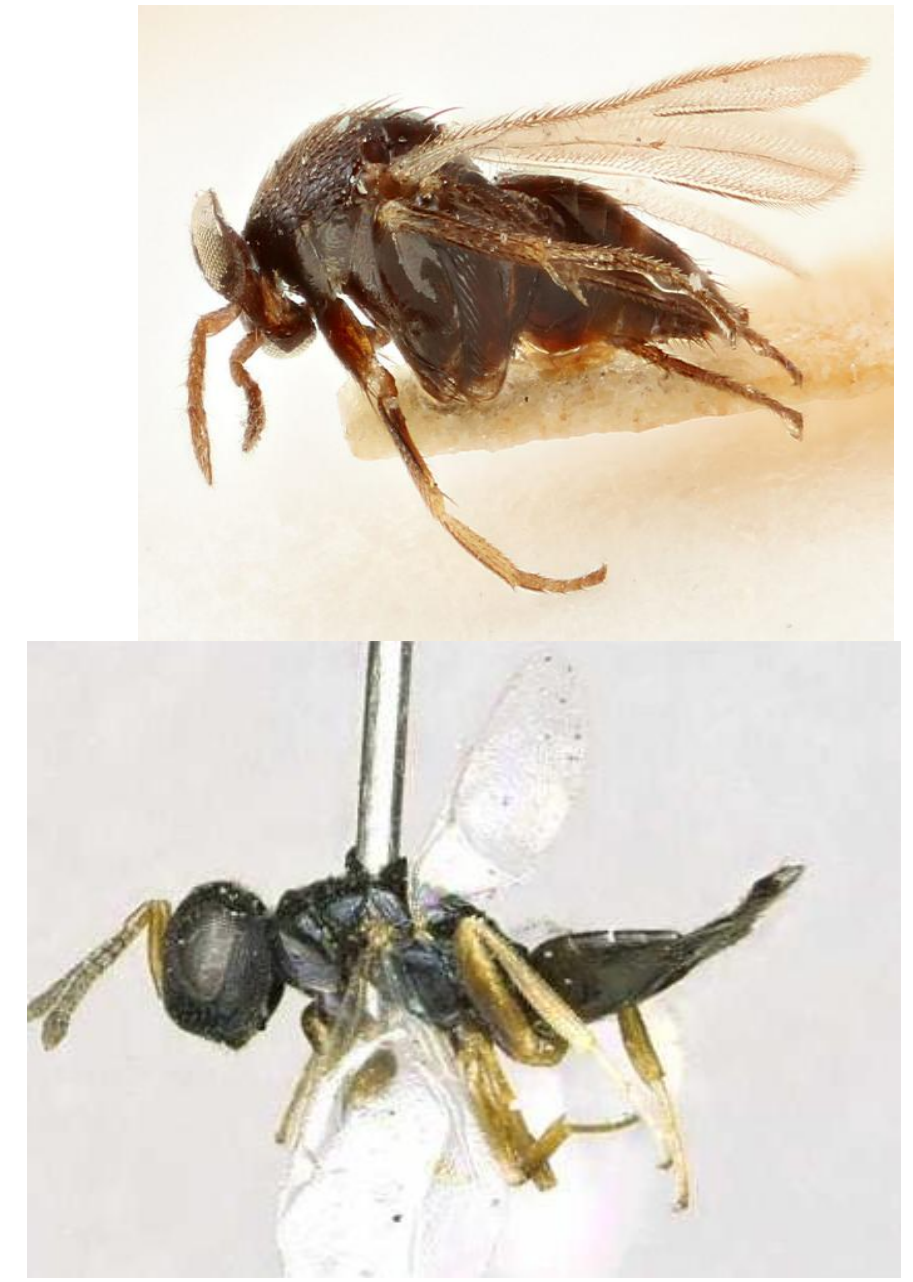

Figure 1.

Appearance of the parasite Elasmus albipennis and Dibrachys cavus.

The parasite is very small, 2 to $3 \mathrm{~mm}$ in size, and the front legs consist of 5 joints. The appearance is brown and has two pairs of wings. It is very active and looks for its prey up to 200 meters per day. They lay their eggs in one or two pieces of apple fruit worms (cocoon).

Another species is the Dibrachyscavus Walk of the Pteromalidae family was first encountered in the agrobiocenosis of the country. Many literary and electronic sources have been analyzed in this regard. Phytophagy in the garden agrobiocenosis has been found in fruit gardens from CIS countries in Russia, Ukraine, Belarus, Turkmenistan, and Azerbaijan. The parasite is parasitized in the pupa of the apple fruit. Because the parasite is very active, it also parasites in the pupa of other types of cornea (moths, Agrotis segetum, pyralids). 


\section{PELITA}

\section{Discussions}

At first, in 2016, in the garden of fruit trees of biochemical intensive Limited Company in the Andijan district of Andijan region it was identified in the wintering pupa of harvested fruiteater in the first ten days of March. The size of the parasite is $3 \mathrm{~mm}$. One pupa can lay 2-6 eggs, depending on its size. It spends all its developmental stages in the shell. At the end of the development, the master flies out of the pupa turning into the larva. It is considered to be non-persistant to frost and dies up to $80 \%$ at $-5-10 \mathrm{C}$. In the wintering stages, in the host pupas spend 1-2 years of worms.

At the same time, the number of pest species can also be determined by the density of entomophagous species. The nutritional factor plays a key role here. For example, the frequent occurrence of leaf twisters and fruit-eaters results in a high number of parasitic entomophages. Many species of sucking pests attract predatory entomophages. Developing and introducing technologies for the cultivation of gardening species and wide application in horticulture is being implemented. According to it, seven points of reproduction and application of afilinides against plant lice include the use and application of yellow trichogramma, reproduction and application of wild mites.

\section{CONCLUSION}

The above-mentioned data are important for the formation of a garden entomofauna, the proportionality of phytosan species, and the removal of missing species. Intermediate crops in fruit orchards are also important in the formation of entomofauna. For example, entomofauna is more concentrated in fruit orchards with alfalfa than in gardens with pods. Especially entomophages have a lot of spare. However, sucking phytophages are also common in alfalfa and damaged fruit trees(Reisinger \& Turner, 1998).

\section{E. REFERENCE}

Craumer, P. (1995). Rural and agricultural development in Uzbekistan. Retrieved from https://www.cabdirect.org/cabdirect/abstract/19986771299

Dennis, E., Ilyasov, J., van Dusen, E., Treshkin, S., Lee, M., \& Eyzaguirre, P. (2007). Local Institutions and Plant Genetic Conservation: Exchange of Plant Genetic Resources in 


\section{PELITA}

Rural Uzbekistan and some Theoretical Implications. World Development, 35(9), 15641578. https:/ / doi.org/10.1016/j.worlddev.2006.05.022

Egamberdieva, D., Kamilova, F., ... S. V.-E., \& 2008, undefined. (n.d.). High incidence of plant growth- stimulating bacteria associated with the rhizosphere of wheat grown on salinated soil in Uzbekistan. Wiley Online Library. Retrieved from http://onlinelibrary.wiley.com/doi/10.1111/j.1462-2920.2007.01424.x/full

Kalpakjian, S., \& Schmid, S. (2014). Manufacturing engineering and technology. Retrieved from https://www.researchgate.net/profile/Vijay_Sekar2/publication/262156319_Manu facturing_Engineering_and_Technology/links/00b49536c9c352428b000000.pdf

Reisinger, Y., \& Turner, L. (1998). Journal of Travel \& Tourism Cross-Cultural Differences in Tourism : A Strategy for Tourism Marketers. Journal of Travel \& Tourism Marketing, 7(4), 79-106. https://doi.org/10.1300/J073v07n04

Sauvach A.Kh., Musolin D.L. Biology and ecology of parasitic hymenoptera (Hymeneptera: Apocrita: Parasitica). St. Petersburg. 2013.-p3.

Sauvach A.H., Musolin D.L. Biology and Ecology of pest hymenoptera (Hymeneptera: Apocrita: Parasitica). St. Petersburg. 2013.-p.3

Koladeva L.M. Key to harmful and beneficial insects and ticks of fruit and berry crops in Leningrad. "Spike" 1984. P. 32-33.

Sternshchis M.V., Dzhalilov U., Andreeva I.V., Tomilova O.G. Biological protection of the plant "Kolos" -Moscow: 2004. p. 101.

Khamraev A.Sh., Nasriddinov K. Biological protection of plants. Publication of People's Heritage. Tashkent 2003. 212 p.

Thomas, K., Thanopoulos, R., Knüpffer, H., \& Bebeli, P. J. (2013). Plant genetic resources in a touristic island: The case of Lefkada (Ionian Islands, Greece). Genetic Resources and Crop Evolution, 60(8), 2431-2455. https://doi.org/10.1007/s10722-013-0011-3 